\title{
Study on the Factors Affecting the Start-Up of Iron-Manganese Co-Oxide Filters for Ammonium and Manganese Removal from Groundwater
}

\author{
Ya Cheng ${ }^{1,2} \mathbb{1}$, Tinglin Huang ${ }^{1,2, *}$, Lijie Cheng ${ }^{1,2}$ and Junbin $\mathrm{Wu}^{1,2}$ \\ 1 Key Laboratory of Northwest Resource, Environment and Ecology, Ministry of Education (MOE), \\ Xi'an University of Architecture and Technology, Xi'an 710055, China; chengya.xauat@outlook.com (Y.C.); \\ 15129883602@163.com (L.C.); junbingwu@foxmail.com (J.W.) \\ 2 Shaanxi Key Laboratory of Environmental Engineering, Xi'an University of Architecture and Technology, \\ Xi'an 710055, China \\ * Correspondence: huangtinglin@xauat.edu.cn; Tel.: +86-029-822-01038; Fax: +86-029-822-02729
}

Received: 27 July 2018; Accepted: 21 August 2018; Published: 23 August 2018 check for
updates

\begin{abstract}
The high concentration of ammonium $\left(\mathrm{NH}_{4}{ }^{+} \mathrm{N}\right)$ and manganese $\left(\mathrm{Mn}^{2+}\right)$ in underground water poses a major problem for drinking water treatment plants. Effective catalytic oxidative removal of $\mathrm{NH}_{4}{ }^{+}-\mathrm{N}$ and $\mathrm{Mn}^{2+}$ by iron-manganese co-oxide film $\left(\mathrm{MeO}_{\mathrm{x}}\right)$ filters was first developed by our group in a previous study. In this study, several identical pilot-scale filters were employed to optimize the start-up process for simultaneous removal of $\mathrm{NH}_{4}{ }^{+}-\mathrm{N}$ and $\mathrm{Mn}^{2+}$ from potable water supplies. Experiments were conducted to assess the influence of $\mathrm{Mn}^{2+}$ concentration, $\mathrm{Fe}^{2+}$ concentration, filtration rate and dosing time on the start-up period of the filter. Results demonstrated that the ability of the filter to remove completely $1.5 \mathrm{mg} / \mathrm{L} \mathrm{NH}_{4}{ }^{+}-\mathrm{N}$ could be achieved on the sixth day at the soonest and the removal of $\mathrm{Mn}^{2+}$ could reach $1 \mathrm{mg} / \mathrm{L}$ by the 18th day. Filter R3 feeding with $1 \mathrm{mg} / \mathrm{L} \mathrm{Fe}^{2+}, 2 \mathrm{mg} / \mathrm{L} \mathrm{Mn}^{2+}$ and $3.5 \mathrm{mg} / \mathrm{L} \mathrm{MnO}_{4}{ }^{-}$during the start-up period exhibited the optimum $\mathrm{NH}_{4}{ }^{+}-\mathrm{N}$ and $\mathrm{Mn}^{2+}$ removal effect. Short dosing time was not conducive to attaining full $\mathrm{NH}_{4}{ }^{+}-\mathrm{N}$ removal in filters, especially the activity of $\mathrm{NO}_{2}{ }^{-}-\mathrm{N}$ conversion to $\mathrm{NO}_{3}{ }^{-}-\mathrm{N}$. The compositional analysis and element distribution analysis results demonstrated that there was an abundance of $\mathrm{C}$, $\mathrm{O}, \mathrm{Mn}, \mathrm{Mg}, \mathrm{Fe}, \mathrm{Ca}$ and $\mathrm{Si}$ across the entire area of the surface of the filter media and the elemental distribution was homogeneous, which was different from the biofilter media. Knowledge-guided performance optimization of the active iron-manganese co-oxide could pave the way for its future technological use.
\end{abstract}

Keywords: iron-manganese co-oxide; filter; start-up; ammonium removal; manganese

\section{Introduction}

Ammonium $\left(\mathrm{NH}_{4}{ }^{+}-\mathrm{N}\right)$ and manganese $(\mathrm{Mn})$ contamination of groundwater is one of the problems faced in water treatment [1]. The presence of $\mathrm{Mn}$ in drinking water causes pipes to clog from the oxidation of $\mathrm{Mn}^{2+}$, which is precipitated as $\mathrm{Mn}^{4+}$ in the form of manganese oxide $\left(\mathrm{MnO}_{2}\right)$, resulting in black colored water [2,3]. Importantly, Mn can cause neurotoxicity in humans. Additionally, in water supply plants, $\mathrm{NH}_{4}{ }^{+}-\mathrm{N}$ in raw water needs to be removed before the water is disinfected with chlorine, as it consumes significant amounts of chlorine and produces chloramines during the disinfection process [4]. The presence of $\mathrm{NH}_{4}{ }^{+}-\mathrm{N}$ in water systems also leads to oxygen depletion, toxicity to fish, eutrophication of surface waters, human nervous system damage and deterioration in the taste and odor of water [5]. The treatment of $\mathrm{NH}_{4}{ }^{+}-\mathrm{N}$ and $\mathrm{Mn}^{2+}$ to reduce the amount to below maximum concentration limits is a priority in drinking water treatment plants. Therefore, for some water supply plants, removal of $\mathrm{NH}_{4}{ }^{+}-\mathrm{N}$ and $\mathrm{Mn}^{2+}$ from groundwater is a daily requirement. 
In order to solve this problem, various treatment technologies have been used to remove $\mathrm{NH}_{4}{ }^{+}-\mathrm{N}$ and $\mathrm{Mn}^{2+}$ from potable water, including biological and physicochemical methods [6-10]. Biofilters, as a biological treatment method, have been widely applied, with the advantages of simple processing technology, strong processing capacity and low investment cost $[4,11,12]$. However, the start-up period of the biological filter column usually takes months [13-16]. Hence, considerable effort has been made to improve designs for the efficient and economic biological removal of $\mathrm{NH}_{4}{ }^{+}-\mathrm{N}$ and $\mathrm{Mn}^{2+}$ [17]. Han et al. systematically investigated the effect of operation factors, such as hydraulic loading, air-to-water ratio and feed ammonium concentration, on simultaneous removal of $\mathrm{NH}_{4}{ }^{+}-\mathrm{N}$ and $\mathrm{Mn}^{2+}$ using a pilot-scale biological aerated filter. They demonstrated that distribution of ammonia oxidizing bacteria and manganese oxidizing bacteria could be a main factor affecting the system performance for simultaneous removal of $\mathrm{NH}_{4}{ }^{+}-\mathrm{N}$ and $\mathrm{Mn}^{2+}$ [18]. In order to shorten the start-up period of the biofilter for the removal of $\mathrm{Fe}^{2+}, \mathrm{Mn}^{2+}$ and $\mathrm{NH}_{4}{ }^{+}-\mathrm{N}$ simultaneously, Cai et al. introduced lab-scale biofilters with three different methods of inoculation. The start-up method that was most effective involved inoculation with nitrifying sludge first, followed by backwashing sludge obtained by backwashing the other matured $\mathrm{Fe}$ and $\mathrm{Mn}$ removal biofilters in the laboratory after complete $\mathrm{NH}_{4}{ }^{+}-\mathrm{N}$ removal. This method required 30 days to achieve complete removal of $\mathrm{Mn}^{2+}$ [19]. In addition, the sludge used in inoculation is a threat to the safety of drinking water treatment, because the sludge may contain metals or other potential pollutants [20].

Unlike biofilters, our group has employed physicochemical technology to start up filters which are used to enhance potable water quality by removing $\mathrm{NH}_{4}{ }^{+}-\mathrm{N}$ and $\mathrm{Mn}^{2+}$ [21,22]. Different from the above traditional biological $\mathrm{NH}_{4}{ }^{+}-\mathrm{N}$ and $\mathrm{Mn}^{2+}$ removal filter columns, the removal of $\mathrm{NH}_{4}{ }^{+}-\mathrm{N}$ was achieved by the chemical catalytic oxidation of iron-manganese co-oxide film coated on the filter media and not by biological degradation. The effective catalytic oxidation of $\mathrm{NH}_{4}{ }^{+}-\mathrm{N}$ by iron-manganese co-oxide film was already verified in our previous study [22]. The mineral structure of oxide film toward $\mathrm{NH}_{4}{ }^{+}-\mathrm{N}$ oxidation was studied systematically and the $\mathrm{NH}_{4}{ }^{+}-\mathrm{N}$ removal mechanisms by oxide film catalytic oxidation have been proposed [23].

The method used to shorten the start-up period is of considerable importance for the further application of this technology. In order to efficiently and economically remove $\mathrm{NH}_{4}{ }^{+}-\mathrm{N}$ and $\mathrm{Mn}^{2+}$, this study attempted to optimize the ripening periods of the removal filters to possibly help reduce the typically long ripening periods. This paper focuses on how to shorten the start-up period of the filter for the removal of $\mathrm{NH}_{4}{ }^{+}-\mathrm{N}$ and $\mathrm{Mn}^{2+}$, by starting up the pilot-scale filters with different feedwater. Pilot experiments were carried out to evaluate the influence of $\mathrm{Mn}^{2+}$ concentration, $\mathrm{Fe}^{2+}$ concentration, filtration rate and dosing time on the start-up of the filter.

\section{Methods}

\subsection{Experimental Set-Up and Feed Water}

A gravity filter made of Plexiglass was adopted for the simultaneous $\mathrm{NH}_{4}{ }^{+}-\mathrm{N}$ and $\mathrm{Mn}^{2+}$ removal process. Each filter had an inner diameter of $100 \mathrm{~mm}$ and was filled with quartz sand of size fraction $0.75-1.2 \mathrm{~mm}$, with a height of $1.10 \mathrm{~m}$. Quartz sand was purchased from a local waterworks. Before the experiment, $1 \mathrm{~mol} / \mathrm{L} \mathrm{HCl}$ was used to soak the quartz sand for 1 day, then was rinsed off. In order to prevent the leakage of quartz sand, a layer of cobblestone was set below the sand as a supporting material with a height of $20 \mathrm{~cm}$ and a particle size of $8-15 \mathrm{~mm}$. The filter column was operated in down flow mode at a filtration efficiency of $4 \mathrm{~m} / \mathrm{h}$ and backwashing process consisted of air backwash, air-water backwash and water backwash. In each step, the intensity of air and water backwash was 13-17 and 3-4 L/(s. $\left.\mathrm{m}^{2}\right)$, respectively. Eight sampling points (located at 0, 10, 22, 35, 55, 75, 95 and $115 \mathrm{~cm}$ from bottom to top) were attached along the height of the column to allow the sampling of water. A schematic diagram of the pilot scaled filter system is shown in Figure 1. The feed water of the filters used in the present study was groundwater obtained from a water source well in Xi'an, China. 
The compositions of the groundwater used in this study are provided in Table 1. Iron and manganese were nearly removed before using the groundwater for the experiment.

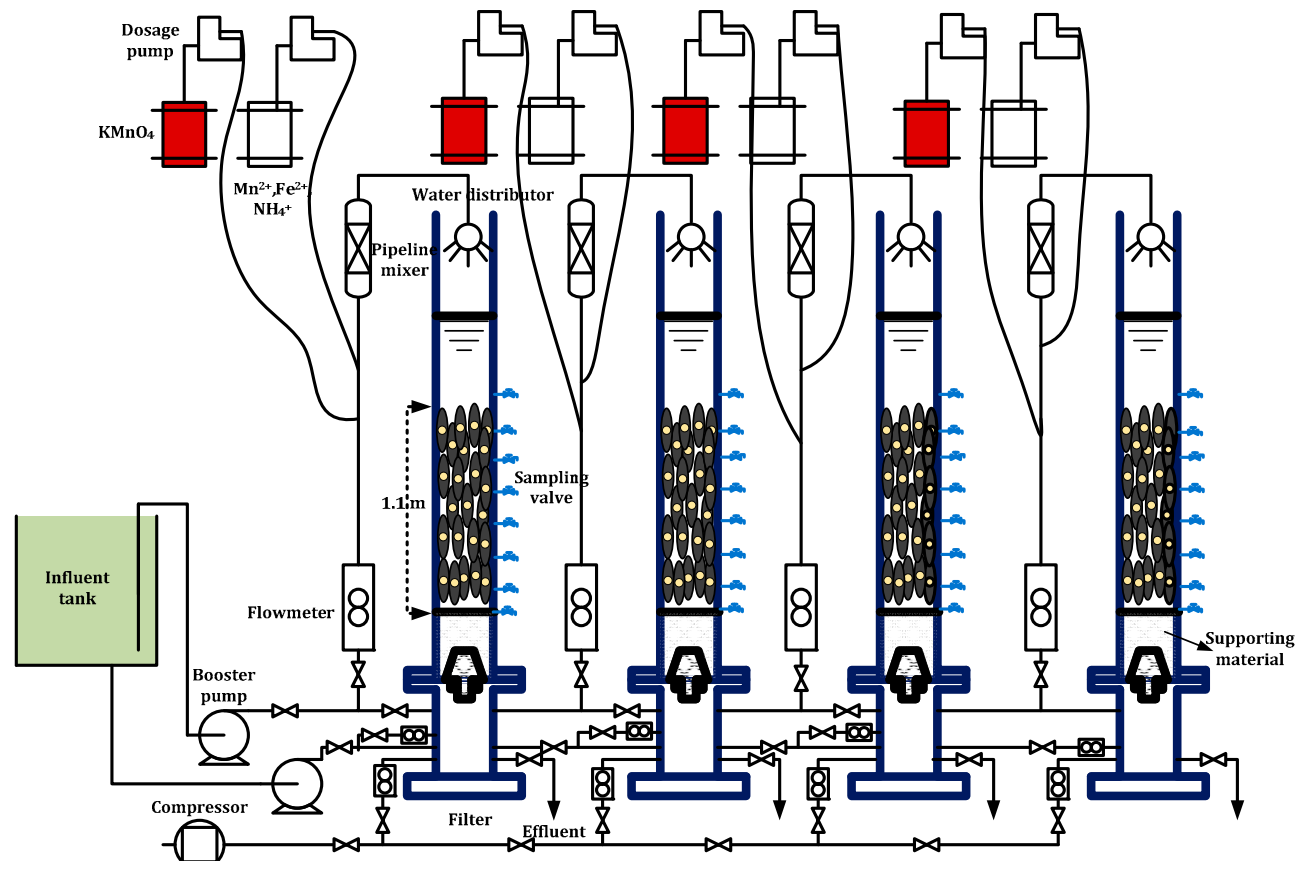

Figure 1. Schematic illustration of the pilot-scale filter system.

Table 1. Chemical composition of the feed water.

\begin{tabular}{lcc}
\hline Parameters & Unit & Value \\
\hline $\mathrm{Cl}^{-}$ & $\mathrm{mg} / \mathrm{L}$ & $60-65$ \\
$\mathrm{SO}_{4}{ }^{2-}$ & $\mathrm{mg} / \mathrm{L}$ & $95-110$ \\
$\mathrm{Ca}^{2+}$ & $\mathrm{mg} / \mathrm{L}$ & $35-40$ \\
$\mathrm{Mg}^{2+}$ & $\mathrm{mg} / \mathrm{L}$ & $23-25$ \\
$\mathrm{Temperature}$ & ${ }^{\circ} \mathrm{C}$ & $15-18$ \\
$\mathrm{pH}$ & - & $7.5-7.8$ \\
$\mathrm{Alkalinity}\left(\mathrm{CaCO}_{3}\right)$ & $\mathrm{mg} / \mathrm{L}$ & $200-250$ \\
$\mathrm{Fe}$ & $\mathrm{mg} / \mathrm{L}$ & $0-0.13$ \\
$\mathrm{Mn}$ & $\mathrm{mg} / \mathrm{L}$ & $0-0.08$ \\
$\mathrm{NH}_{4}{ }^{+}-\mathrm{N}$ & $\mathrm{mg} / \mathrm{L}$ & $0-0.2$ \\
$\mathrm{NO}_{3}{ }^{-}-\mathrm{N}$ & $\mathrm{mg} / \mathrm{L}$ & $0-0.40$ \\
$\mathrm{NO}_{2}{ }^{-}-\mathrm{N}$ & $\mathrm{mg} / \mathrm{L}$ & $0-0.003$ \\
$\mathrm{TOC}^{+}$ & $\mathrm{mg} / \mathrm{L}$ & $1-3.5$ \\
$\mathrm{Na}^{+}$ & $\mathrm{mg} / \mathrm{L}$ & $80-90$ \\
$\mathrm{DO}$ & $\mathrm{mg} / \mathrm{L}$ & $2.0-4.0$ \\
\hline
\end{tabular}

TOC: Total organic content; DO: Dissolved oxygen.

\subsection{Start-Up Method for Filters}

For starting up the filters, different start-up methods were applied to optimize the start-up procedure. Booster pumps and tubing were used to pump feed water through the system. The starting principle of the filters was as follows: mixing and dosing potassium permanganate $\left(\mathrm{MnO}_{4}^{-}\right)$, manganese chloride $\left(\mathrm{Mn}^{2+}\right)$ and ferric chloride $\left(\mathrm{Fe}^{2+}\right)$ with peristaltic pump; the formed oxides along with the raw water enter into the filter system; the oxides can be retained by the processes of filtration then forming a film of catalytically active metal oxide coated on the filter media, after prolonged filter runs. During the start-up period, $\mathrm{MnO}_{4}{ }^{-}, \mathrm{Mn}^{2+}$ and $\mathrm{Fe}^{2+}$ were mixed with a mole ratio of complete reaction, shown in Equations (1) and (2), to avoid excessive dosage of $\mathrm{MnO}_{4}^{-}$, which would 
damage the development of the oxides film. During the operation period, in order to detect $\mathrm{NH}_{4}{ }^{+}-\mathrm{N}$ removal efficiency of the filter in time, $\mathrm{NH}_{4} \mathrm{Cl}$ was also dosed into the influent and the influent $\mathrm{NH}_{4}{ }^{+}-\mathrm{N}$ concentration was kept at $1.5 \mathrm{mg} / \mathrm{L}$ :

$$
\begin{gathered}
2 \mathrm{MnO}_{4}{ }^{-}+3 \mathrm{Mn}^{2+}+2 \mathrm{H}_{2} \mathrm{O} \rightarrow 5 \mathrm{MnO}_{2}+4 \mathrm{H}^{+} \\
\mathrm{MnO}_{4}^{-}+3 \mathrm{Fe}^{2+}+4 \mathrm{H}^{+} \rightarrow \mathrm{MnO}_{2}+3 \mathrm{Fe}^{3+}+2 \mathrm{H}_{2} \mathrm{O}
\end{gathered}
$$

Several identical pilot-scale gravity filters were adopted in this study. Each filter system was operated continuously for four weeks. To investigate the effect of $\mathrm{Mn}^{2+}$ and $\mathrm{Fe}^{2+}$ concentration on the start-up of filter, $\mathrm{Mn}^{2+}$ and $\mathrm{Fe}^{2+}$ were manually dosed into the influent at a certain concentration and the filtration rate was maintained at $4 \mathrm{~m} / \mathrm{h}$. After 14 days' operation, dosing $\mathrm{MnO}_{4}{ }^{-}, \mathrm{Mn}^{2+}$ and $\mathrm{Fe}^{2+}$ ceased. The ability to remove manganese was evaluated by varying the influent $\mathrm{Mn}^{2+}$ concentration of the filters on the 8th, 18th and 28th day. In order to study the effect of filtration rate on the start-up of the filters, the filtration rate increased from 4 to $6 \mathrm{~m} / \mathrm{h}$ with other parameters kept constant. In addition, the effect of the dosing time $\left(\mathrm{MnO}_{4}{ }^{-}, \mathrm{Mn}^{2+}\right.$ and $\left.\mathrm{Fe}^{2+}\right)$ on the start-up of the filters was also studied. Too high a $\mathrm{Mn}^{2+}$ and $\mathrm{Fe}^{2+}$ concentration could lead to too frequent backwashing. Therefore, in this study, the $\mathrm{Fe}^{2+}$ concentration was $0-2 \mathrm{mg} / \mathrm{L}$, whereas the maximum $\mathrm{Mn}^{2+}$ concentration was set to $4 \mathrm{mg} / \mathrm{L}$. The operating parameters of the filters (named R1, R2, R3, R4, R5, R6 and R7) in this study are presented in Table 2.

Table 2. The operating parameters of all the filters during operation period (start-up period and normal

\begin{tabular}{|c|c|c|c|c|c|c|c|c|c|c|}
\hline \multirow[b]{2}{*}{ Name } & \multicolumn{7}{|c|}{ Start-Up Period Normal } & \multicolumn{3}{|c|}{ Operation Period } \\
\hline & $\begin{array}{l}\mathrm{c}\left(\mathrm{Mn}^{2+}\right) \\
(\mathrm{mg} / \mathrm{L})\end{array}$ & $\begin{array}{l}\mathrm{c}\left(\mathrm{Fe}^{2+}\right) \\
(\mathrm{mg} / \mathrm{L})\end{array}$ & $\begin{array}{l}\mathrm{c}\left(\mathrm{MnO}_{4}{ }^{-}\right) \\
(\mathrm{mg} / \mathrm{L})\end{array}$ & $\begin{array}{c}\mathrm{c}\left(\mathrm{NH}_{4}{ }^{+}-\mathrm{N}\right) \\
(\mathrm{mg} / \mathrm{L})\end{array}$ & $\begin{array}{c}v \\
(\mathrm{~m} / \mathrm{h})\end{array}$ & $\begin{array}{l}\text { Backwashing } \\
\text { Frequency }\end{array}$ & $\begin{array}{c}\mathrm{T}^{*} \\
\text { (day) }\end{array}$ & $\begin{array}{c}\mathrm{c}\left(\mathrm{NH}_{4}{ }^{+}-\mathrm{N}\right) \\
(\mathrm{mg} / \mathrm{L})\end{array}$ & $\begin{array}{c}v \\
(\mathrm{~m} / \mathrm{h})\end{array}$ & $\begin{array}{c}\text { Backwashing } \\
\text { Frequency }\end{array}$ \\
\hline R1 & 2 & 0 & 2.8 & 1.5 & 4 & 2 days & 14 & 1.5 & 6 & 2 days \\
\hline R2 & 2 & 0.5 & 3.2 & 1.5 & 4 & 2 days & 14 & 1.5 & 6 & 2 days \\
\hline R3 & 2 & 1.0 & 3.5 & 1.5 & 4 & 2 days & 14 & 1.5 & 6 & 2 days \\
\hline R4 & 2 & 2.0 & 4.2 & 1.5 & 4 & 2 days & 14 & 1.5 & 6 & 2 days \\
\hline R5 & 4 & 1.0 & 6.4 & 1.5 & 4 & 1 days & 14 & 1.5 & 6 & 2 days \\
\hline R6 & 4 & 1.0 & 6.4 & 1.5 & 6 & 12 hours & 14 & 1.5 & 6 & 2 days \\
\hline R7 & 2 & 1.0 & 3.5 & 1.5 & 4 & 2 days & 4 & 1.5 & 6 & 2 days \\
\hline
\end{tabular}
operation period).

\subsection{Analytical Methods}

During the experimental runs, effluent samples were collected in polypropylene bottles. Manganese presented as $\mathrm{Mn}^{2+}$ was analyzed with the 1-(2-pyridylazo)-2-naphthol (PAN) method at an absorbance of $560 \mathrm{~nm}$ using a HACH DR 5000 instrument (Hach Company, Loveland, CO, USA). The levels of $\mathrm{NH}_{4}{ }^{+}-\mathrm{N}$ were determined spectrophotometrically with the Nesslerization method at an absorbance of $425 \mathrm{~nm}$ using the same HACH DR 5000 unit. Nitrate $\left(\mathrm{NO}_{3}{ }^{-}-\mathrm{N}\right)$ was analyzed by diazotization method also using the HACH DR 5000 and nitrite $\left(\mathrm{NO}_{2}{ }^{-}-\mathrm{N}\right)$ was also detected by spectrophotometry in accordance with standard methods. The dissolved oxygen (DO) and $\mathrm{pH}$ were determined by a portable instrument (HQ30d, Hach Company, Loveland, CO, USA).

A sample of $1.5 \mathrm{~g}$ of sand was taken from the top of each filtration column to carry out scanning electron microscope (SEM), Brunauer-Emmett-Teller (BET) and energy dispersive spectrometer (EDS) mapping testing. The morphology of the samples was observed using a field emission SEM (FEI Quanta 600F, Hillsboro, OR, USA). The surface and porous properties of the adsorbent were studied using nitrogen adsorption experiments realized with autosorb-1 (Quantachrome Instruments, Boynton Beach, FL, USA) at $-196{ }^{\circ} \mathrm{C}$ with a heating rate of $10 \mathrm{~K} / \mathrm{min}$. The specific BET surface area and pore size of the adsorbent were evaluated according to the BET method. Multi-elemental EDS mapping was collected by an INCA IE350 x-ray spectrometer (Oxford Instruments, Abingdon, UK). 


\section{Results and Discussion}

\subsection{Effect of $\mathrm{Fe}^{2+}$ Concentrations on the Start-Up of the Filters}

\subsubsection{The $\mathrm{NH}_{4}{ }^{+}-\mathrm{N}$ Removal Performance during the Start-Up Period}

In this study, four identical pilot-scale filters were used to explore the effect of $\mathrm{Fe}^{2+}$ concentrations on the start-up of filter. The influent $\mathrm{Fe}^{2+}$ concentrations were 0 (filter R1), 0.5 (filter R2), 1 (filter R3) and $2.0 \mathrm{mg} / \mathrm{L}$ (filter R4). The experimental results are shown in Figure 2. During the first two days, the influent and effluent $\mathrm{NH}_{4}{ }^{+}-\mathrm{N}$ concentration of these four filters remained basically the same, which indicated that the adsorption capacity of virgin sand to $\mathrm{NH}_{4}{ }^{+}-\mathrm{N}$ could be ignored. From the third day, $\mathrm{NH}_{4}{ }^{+}-\mathrm{N}$ removal capacity of the filters increased gradually. At a nearly constant influent $\mathrm{NH}_{4}{ }^{+}-\mathrm{N}^{-}$ concentration of $1.5 \mathrm{mg} / \mathrm{L}$, the effluent $\mathrm{NH}_{4}{ }^{+}-\mathrm{N}$ concentration of filters $\mathrm{R} 1, \mathrm{R} 2, \mathrm{R} 3$ and $\mathrm{R} 4$ could meet the drinking water quality standard in China $(<0.5 \mathrm{mg} / \mathrm{L})$ by the eighth, seventh, fourth and fifth day, respectively. With prolonging the running time, the influent $\mathrm{NH}_{4}{ }^{+}-\mathrm{N}$ could be eliminated at the 15 th, 13th, 6th and 18th day for filters R1, R2, R3 and R4, respectively. The start-up period for the filters was much faster than that of the biofilters [15]. It should be noted that the big difference among the four filters was that the $\mathrm{NH}_{4}{ }^{+}-\mathrm{N}$ removal efficiency of filters $\mathrm{R} 1, \mathrm{R} 2$ and $\mathrm{R} 4$ from day 4 to 12 increased slower than that of filter R3.

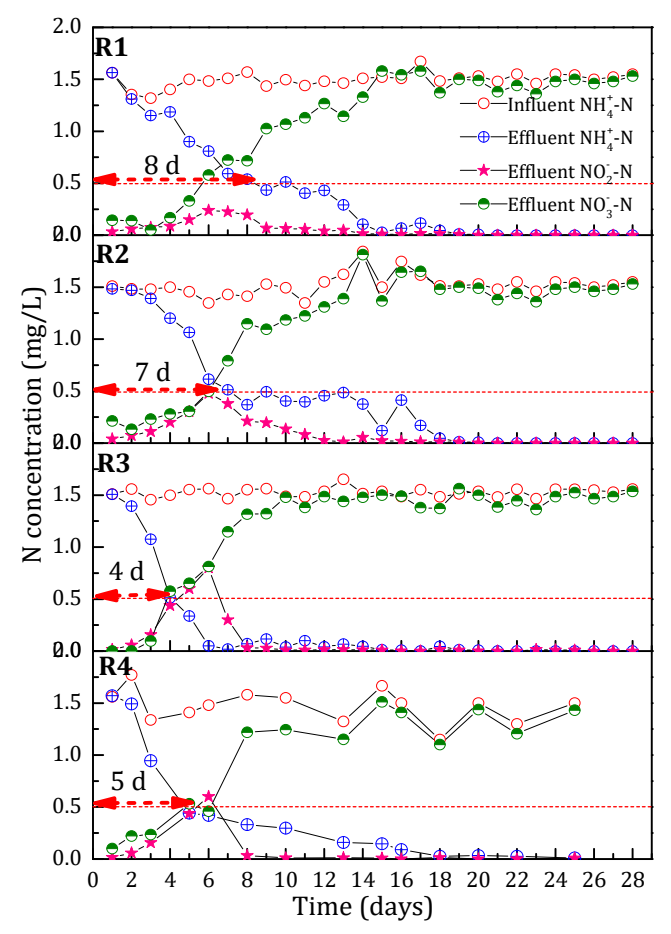

Figure 2. The effect of influent $\mathrm{Fe}^{2+}$ concentration on the variation of $\mathrm{N}\left(\mathrm{NH}_{4}{ }^{+}-\mathrm{N}, \mathrm{NO}_{3}{ }^{-}-\mathrm{N}\right.$ and $\mathrm{NO}_{2}{ }^{-}-\mathrm{N}$ ) concentration during the start-up period.

During the first 10 days, the accumulation of $\mathrm{NO}_{2}{ }^{-}-\mathrm{N}$ was accompanied with rapidly increased $\mathrm{NH}_{4}{ }^{+}-\mathrm{N}$ removal capacity. Over time, $\mathrm{NO}_{2}{ }^{-}-\mathrm{N}$ was negatively correlated with the accumulation peak of $\mathrm{NO}_{2}{ }^{-}-\mathrm{N}$. The accumulation time of $\mathrm{NO}_{2}{ }^{-}-\mathrm{N}$ : filter $\mathrm{R} 1$ (14 days) > filter $\mathrm{R} 2$ (12 days) > filter $\mathrm{R} 4$ (10 days) > filter $\mathrm{R} 3$ (8 days). The accumulation peak of $\mathrm{NO}_{2}{ }^{-}-\mathrm{N}$ in filter $\mathrm{R} 3$ with the shortest accumulation time was $0.8 \mathrm{mg} / \mathrm{L}$. The accumulation peak of $\mathrm{NO}_{2}{ }^{-}-\mathrm{N}$ in filter $\mathrm{R} 1$ with the longest accumulation time was $0.24 \mathrm{mg} / \mathrm{L}$. Jiang et al. reported that the accumulation of $\mathrm{NO}_{2}{ }^{-}-\mathrm{N}$ in biofilters was related to the level of DO condition [24]. However, in this study, the influent DO of all the filters was almost the same, which could meet the oxygen demand of $\mathrm{NH}_{4}{ }^{+}-\mathrm{N}$ removal. So it could be 
inferred that the accumulation of $\mathrm{NO}_{2}{ }^{-}-\mathrm{N}$ was due to the lack of $\mathrm{NO}_{2}{ }^{-}-\mathrm{N}$ catalytic oxidation activity of the filter media.

\subsection{2. $\mathrm{Mn}^{2+}$ Removal Performance during the Start-Up Period}

During the start-up period, $\mathrm{MnO}_{4}{ }^{-}, \mathrm{Mn}^{2+}$ and $\mathrm{Fe}^{2+}$ reacted completely and $\mathrm{Mn}^{2+}$ and $\mathrm{Fe}^{2+}$ were hardly detectable in the influent water. In order to investigate the variation in manganese removal capacity of the filters with running time, the experiments were conducted on the 8th, 18th and 28th day. The concentration of $\mathrm{Mn}^{2+}$ in the influent was kept at $2 \mathrm{mg} / \mathrm{L}$. The variation of $\mathrm{Mn}^{2+}$ concentration along the depth of the filters is shown in Figure 3. The removal capacity of the filter column along the depth of the filter gradually increased.

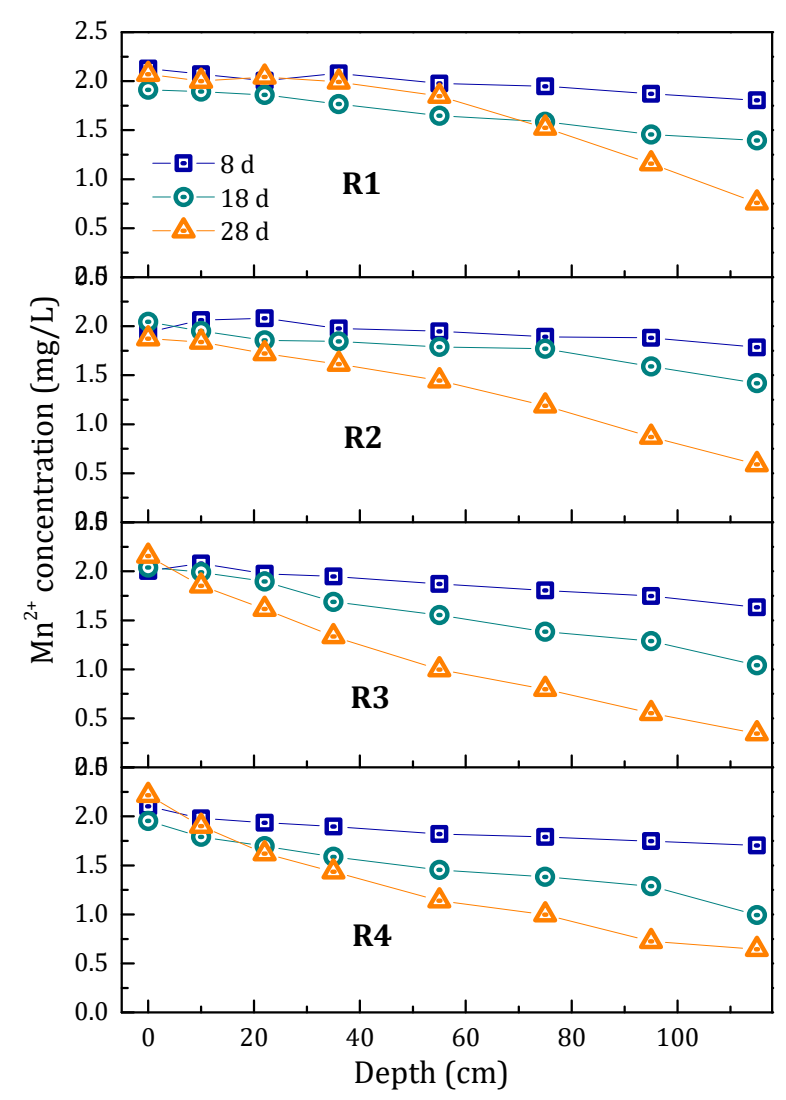

Figure 3. The effect of influent $\mathrm{Fe}^{2+}$ concentration on the variation of $\mathrm{Mn}^{2+}$ concentration along the depth of the filters at different running time.

The $\mathrm{Mn}^{2+}$ removal of these four filters is presented in Figure 4. The $\mathrm{Mn}^{2+}$ removal amount also increased with running time. At the eighth day, the $\mathrm{Mn}^{2+}$ removal amount was nearly the same for all filters. However, the $\mathrm{Mn}^{2+}$ removal capability of the filters became different afterward, which could be attributed to the different catalytic activities of the filter media. The $\mathrm{Mn}^{2+}$ removal capacity of filters R3 and R4 was higher than that of the other two filters. Considering the dosing concentration of filter $\mathrm{R} 3$ was lower than that of filter $\mathrm{R} 4$, we concluded that a higher $\mathrm{Fe}^{2+}$ concentration of $1 \mathrm{mg} / \mathrm{L}$ produces better results during the start-up period. 


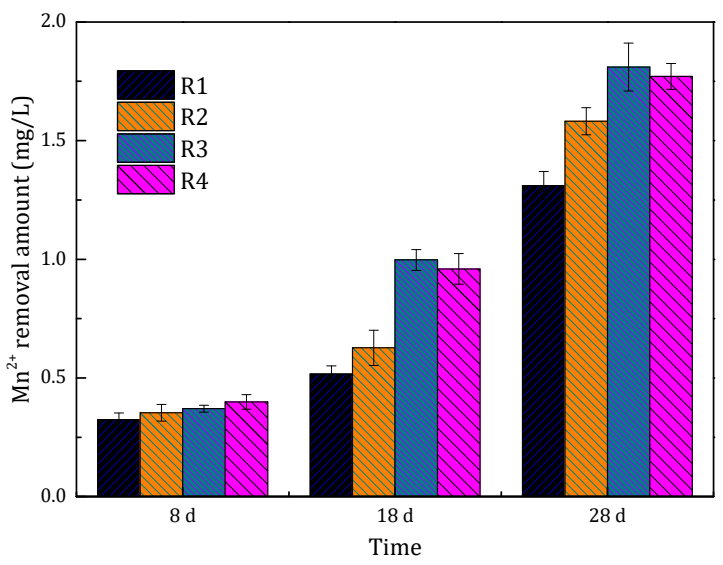

Figure 4. The comparison of the $\mathrm{Mn}^{2+}$ removal of the filters (R1, R2, R3 and R4) at different running time.

\subsubsection{Variation in $\mathrm{pH}$ and $\mathrm{DO}$ during the Start-up Period}

Filter $\mathrm{R} 1$ was selected to study the variation in $\mathrm{pH}$ and $\mathrm{DO}$ with the running time during the operation period, as shown in Figure 5. Theoretically, hydrogen ions $\left(\mathrm{H}^{+}\right)$would be released when $\mathrm{NH}_{4}{ }^{+}-\mathrm{N}$ oxidizes to $\mathrm{NO}_{2}{ }^{-}-\mathrm{N}$ or $\mathrm{NO}_{3}{ }^{-}-\mathrm{N}$ :

$$
\begin{gathered}
\mathrm{NH}_{4}^{+}+1.5 \mathrm{O}_{2} \rightarrow \mathrm{NO}_{2}{ }^{-}+\mathrm{H}_{2} \mathrm{O}+2 \mathrm{H}^{+} \\
\mathrm{NH}_{4}{ }^{+}+2 \mathrm{O}_{2} \rightarrow \mathrm{NO}_{3}{ }^{-}+\mathrm{H}_{2} \mathrm{O}+2 \mathrm{H}^{+}
\end{gathered}
$$

However, compared with the influent $\mathrm{pH}$, the effluent $\mathrm{pH}$ did not change much. This was mainly attributed to the buffering effect of the groundwater with high alkalinity (Table 1). The influent DO remained at 5-7 mg/L. The effluent DO decreased gradually along with the running time, which was in accordance with the $\mathrm{NH}_{4}{ }^{+}-\mathrm{N}$ removal performance (Figure 2). Especially in the first 15 days, the effluent $\mathrm{NH}_{4}{ }^{+}-\mathrm{N}$ and $\mathrm{DO}$ concentration decreased synchronously, but it's worth noting that the DO consumption ( $5 \mathrm{mg} / \mathrm{L})$ for $\mathrm{NH}_{4}{ }^{+}-\mathrm{N}(1.5 \mathrm{mg} / \mathrm{L})$ removal was less than the theoretical DO consumption $(6.8 \mathrm{mg} / \mathrm{L})$ according to Equation (4), which should be caused by the atmospheric reoxygenation during sampling and testing process. Nonetheless, the $\mathrm{NH}_{4}{ }^{+}-\mathrm{N}$ removal capacity of the filters during the start-up period could be evaluated by detecting the change in DO in the influent and effluent.

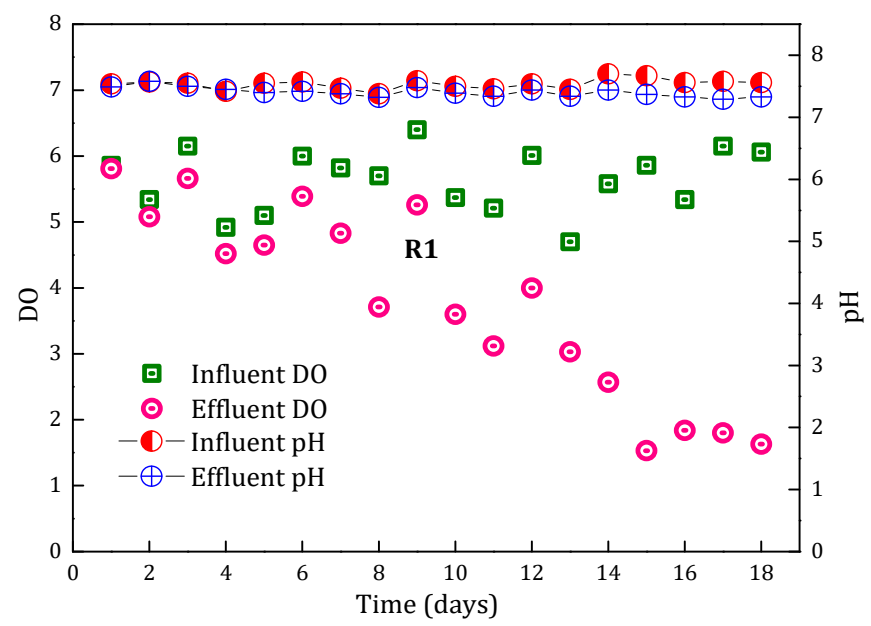

Figure 5. The variation of $\mathrm{pH}$ and dissolved oxygen (DO) in filter $\mathrm{R} 1$ during the start-up period. 


\subsection{Effect of $\mathrm{Mn}^{2+}$ Concentration on the Start-Up of the Filters}

\subsection{1. $\mathrm{NH}_{4}{ }^{+}-\mathrm{N}$ Removal Performance during the Start-Up Period}

As known from the above experimental results, the start-up of filter R3 performed the best. Therefore, in order to further explore the effect of $\mathrm{Mn}^{2+}$ concentration on the start-up of the filters for $\mathrm{NH}_{4}{ }^{+}-\mathrm{N}$ and $\mathrm{Mn}^{2+}$ removal, a filter named $\mathrm{R} 5$ was initiated. During the start-up period, the influent $\mathrm{Fe}^{2+}$ and $\mathrm{NH}_{4}{ }^{+}-\mathrm{N}$ concentration of filter $\mathrm{R} 5$ was the same as that of $\mathrm{R} 3$. The difference was that the influent $\mathrm{Mn}^{2+}$ concentration increased from 2 to $4 \mathrm{mg} / \mathrm{L}$. The comparison of $\mathrm{NH}_{4}{ }^{+}-\mathrm{N}$ removal performance during the start-up period between filter R3 and R5 is shown in Figure 6. Filter R3 with low influent Mn concentration ( $2 \mathrm{mg} / \mathrm{L}$ ) demonstrated better $\mathrm{NH}_{4}{ }^{+}-\mathrm{N}$ removal performance than that of filter R5 with high influent $\mathrm{Mn}^{2+}$ concentration $(4 \mathrm{mg} / \mathrm{L})$. The time at which capacity of $\mathrm{NH}_{4}{ }^{+}-\mathrm{N}$ catalytic oxidation started extended from the first day (filter R3) to the sixth day (filter R5). The effluent $\mathrm{NH}_{4}{ }^{+}-\mathrm{N}$ concentration of filter $\mathrm{R} 3$ met the drinking water quality standard in China $(<0.5 \mathrm{mg} / \mathrm{L})$ on the fourth day, but the time for filter $\mathrm{R} 5$ to obtain the same level of effluent $\mathrm{NH}_{4}{ }^{+}-\mathrm{N}$ concentration required 11 days. Hence, too high a $\mathrm{Mn}^{2+}$ concentration was not beneficial to the formation of $\mathrm{NH}_{4}{ }^{+}-\mathrm{N}$ removal capability of the filters. In addition, we also found that little accumulation of $\mathrm{NO}_{2}{ }^{-}-\mathrm{N}$ appeared in filter R5. This implied that high $\mathrm{Mn}^{2+}$ concentrations were beneficial to the transformation of $\mathrm{NO}_{2}{ }^{-}-\mathrm{N}$.

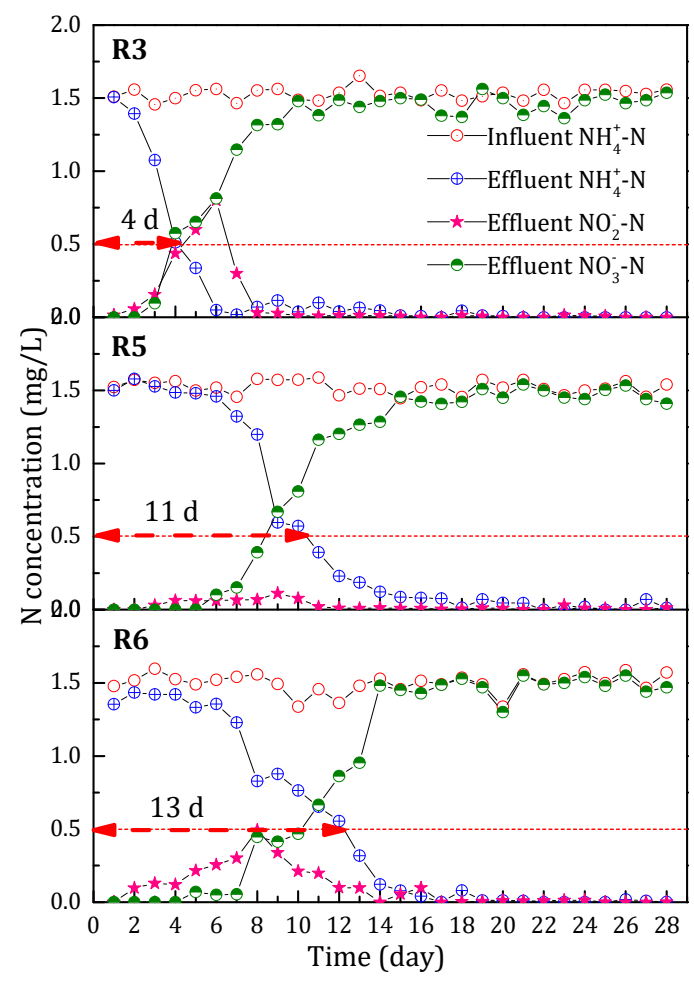

Figure 6. The effect of influent Mn concentration and filtration rate on the variation of $\mathrm{N}\left(\mathrm{NH}_{4}{ }^{+}-\mathrm{N}\right.$, $\mathrm{NO}_{3}{ }^{-}-\mathrm{N}$ and $\mathrm{NO}_{2}{ }^{-}-\mathrm{N}$ ) concentration during the start-up period.

\subsection{2. $\mathrm{Mn}^{2+}$ Removal Performance during the Start-Up Period}

The comparison of the $\mathrm{Mn}^{2+}$ removal amount in filters $\mathrm{R} 3$ and $\mathrm{R} 5$ is shown in Figure 7. The $\mathrm{Mn}^{2+}$ removal ability of filters $\mathrm{R} 3$ and $\mathrm{R} 5$ increased with the running time. The $\mathrm{Mn}^{2+}$ removal performance of filter R3 was much better than that of the filter R5. The $\mathrm{Mn}^{2+}$ removal ability of filter R5 on the 28 th day was even lower than that of filter R3 on the 18th day. During the actual operation of the filters, we found that the frequency of backwashing may affect the $\mathrm{Mn}^{2+}$ removal performance of the filters. Backwashing was carried out every day in filter R5, which was more frequent than for filter R3 (every two days). The higher the $\mathrm{Mn}^{2+}$ concentration, the more frequent the backwashing. Frequent 
backwashing in the filter scoured the oxides coated on the filter media, which resulted in unstable coating of the oxides. Hence, the ability to remove $\mathrm{Mn}^{2+}$ in filter $\mathrm{R} 5$ was weak.

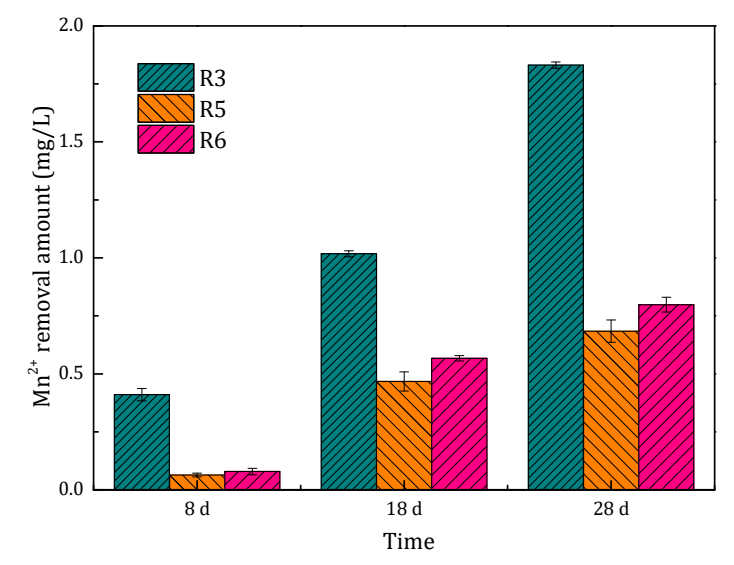

Figure 7. Comparison of the $\mathrm{Mn}^{2+}$ removal amount of the filters (R3, $\mathrm{R} 5$ and $\left.\mathrm{R} 6\right)$ at different running times.

\subsection{Effect of Filtration Rate on the Start-Up of the Filters}

\subsection{1. $\mathrm{NH}_{4}{ }^{+}-\mathrm{N}$ Removal Performance during the Start-Up Period}

In order to further explore the effect of filtration rate on the start-up of the filters for $\mathrm{NH}_{4}{ }^{+}-\mathrm{N}$ removal, a filter named $\mathrm{R} 6$ was adopted. During the start-up period, the influent $\mathrm{MnO}_{4}{ }^{-}, \mathrm{Fe}^{2+}, \mathrm{Mn}^{2+}$ and $\mathrm{NH}_{4}{ }^{+}-\mathrm{N}$ concentrations of the $\mathrm{R} 6$ filter were the same as that of $\mathrm{R} 3$. The only difference was that filtration rate was changed from $4 \mathrm{~m} / \mathrm{h}$ to $6 \mathrm{~m} / \mathrm{h}$. As shown in Figure 6 , the increase of filtration rate had little effect on the removal capacity of $\mathrm{NH}_{4}{ }^{+}-\mathrm{N}$, but it resulted in the obvious accumulation of $\mathrm{NO}_{2}{ }^{-}-\mathrm{N}$. The results indicated that the transformation from $\mathrm{NO}_{2}{ }^{-}-\mathrm{N}$ to $\mathrm{NO}_{3}{ }^{-}-\mathrm{N}$ required longer reaction time than from $\mathrm{NH}_{4}{ }^{+}-\mathrm{N}$ to $\mathrm{NO}_{2}{ }^{-}-\mathrm{N}$.

\subsubsection{The $\mathrm{Mn}^{2+}$ Removal Performance during the Start-Up Period}

The comparison of $\mathrm{Mn}^{2+}$ removal amount between filter $\mathrm{R} 5$ and $\mathrm{R} 6$ is shown in Figure 7. The $\mathrm{Mn}^{2+}$ removal ability of filter R5 and R6 gradually increased with the running time and was basically the same. However, it is worth noting that the $\mathrm{Mn}^{2+}$ removal ability of filters $\mathrm{R} 5$ and $\mathrm{R} 6$ was significantly worse than that of filter R3. This phenomenon was closely related to the frequent backwashing as discussed in Section 3.2.2. During the start-up period, the increase in the filtration rate led to the increase in the influent loads of the filter, similar to the high influent $\mathrm{Mn}^{2+}$ concentration. Backwashing was carried out every $12 \mathrm{~h}$ in filter R5. Therefore, in this study, the optimal filtration rate was $4 \mathrm{~m} / \mathrm{h}$ during the start-up period.

\subsection{Effect of Dosing Time on the $\mathrm{NH}_{4}{ }^{+}-\mathrm{N}$ Removal Performance}

The duration of dosing time determines whether a start-up method is economical. For all filters dosage of $\mathrm{MnO}_{4}{ }^{-}, \mathrm{Fe}^{2+}$ and $\mathrm{Mn}^{2+}$ was stopped at the 14th day. At this point, the effluent $\mathrm{NH}_{4}{ }^{+}-\mathrm{N}$ concentration of the filters could basically satisfy the limited stated in the drinking water quality standard in China and the concentration of $\mathrm{NO}_{2}{ }^{-}-\mathrm{N}$ was also very low. Therefore, in order to further shorten the start-up period and reduce the cost, dosing time was optimized.

A filter named R7 was initiated with the same start-up method as filter R3. However, the dosing time decreased from 14 days to four days. The comparison of $\mathrm{NH}_{4}{ }^{+}-\mathrm{N}$ removal performance is shown in Figure 8.

On the fourth day, the ability of $\mathrm{NH}_{4}{ }^{+}-\mathrm{N}$ removal of filter $\mathrm{R} 7$ was established. At this time, dosing $\mathrm{MnO}_{4}{ }^{-}, \mathrm{Fe}^{2+}$ and $\mathrm{Mn}^{2+}$ was stopped. After then, we found that the rate of $\mathrm{NH}_{4}{ }^{+}-\mathrm{N}$ removal 
decreased in filter R7. The time for $\mathrm{NH}_{4}{ }^{+}-\mathrm{N}$ removal completely extended from day 7 to 11 . Meanwhile, the accumulation of $\mathrm{NO}_{2}{ }^{-}-\mathrm{N}$ became more obvious. The required time extended from 8 days to 15 days when the effluent was completely free of $\mathrm{NO}_{2}{ }^{-}-\mathrm{N}$. Therefore, we concluded that the time when adding $\mathrm{MnO}_{4}{ }^{-}, \mathrm{Fe}^{2+}$ and $\mathrm{Mn}^{2+}$ was too short and not conducive to the full formation of the activity of $\mathrm{NH}_{4}{ }^{+}-\mathrm{N}^{2}$ removal in filters, especially the activity of $\mathrm{NO}_{2}{ }^{-}-\mathrm{N}$ conversion to $\mathrm{NO}_{3}{ }^{-}-\mathrm{N}$.

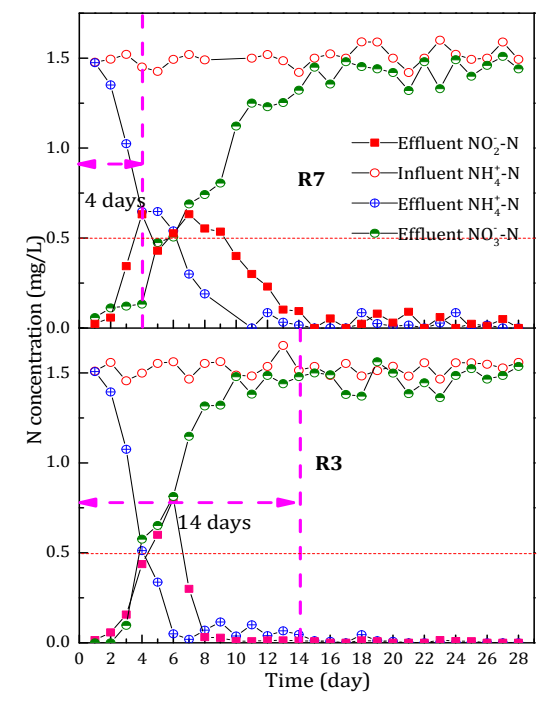

Figure 8. The effect of dosing time on the variation of $\mathrm{N}\left(\mathrm{NH}_{4}{ }^{+}-\mathrm{N}, \mathrm{NO}_{3}{ }^{-}-\mathrm{N}\right.$ and $\left.\mathrm{NO}_{2}{ }^{-}-\mathrm{N}\right)$ concentration during the start-up period.

\subsection{Characterization Studies}

\subsubsection{Morphological Analysis}

The surfaces of the virgin sand and the filter media in filter R3 collected on the 12th day were characterized by SEM, as shown in Figure 9. From Figure 9a, the surface of the virgin sand was smooth. After 12 days' running, the surface of the sand was coated with many oxides, which were formed by the accumulation of small particles, as shown in Figure 9b. Specific surface areas of these samples were further determined using the BET method. The results showed that the specific surface area increased from $0.106 \mathrm{~m}^{2} / \mathrm{g}$ (virgin sand) to $3.920 \mathrm{~m}^{2} / \mathrm{g}$ (filter media collected on 12th day). Cao et al. reported that the increased specific surface area provided more active sites for $\mathrm{NH}_{4}{ }^{+}-\mathrm{N}$ catalytic oxidation, which played a decisive role in the catalytic oxidation process of $\mathrm{NH}_{4}{ }^{+}-\mathrm{N}$ [25].

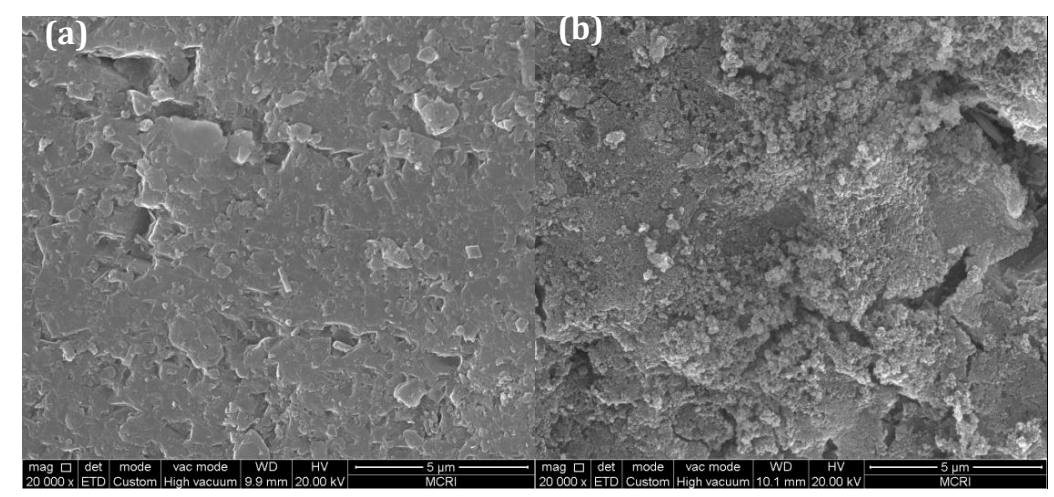

Figure 9. Scanning electronic microscope images of (a) virgin sand and (b) the filter media collected from filter $\mathrm{R} 3$ on the 12 th day. 


\subsubsection{Composition Analysis}

The surface element composition of the virgin sand and the filter media collected on the 12th day was analyzed by EDS. As shown in Table 3, virgin sand mainly contained two elements: silicon $(\mathrm{Si})$ and oxygen $(\mathrm{O})$. After 12 days' operation, the oxides formed on the surface of the sand contained $\mathrm{C}, \mathrm{Mn}, \mathrm{Fe}, \mathrm{Mg}, \mathrm{Ca}, \mathrm{Si}$ and O elements, which was consistent with our previous study [26]. Due to the minimal change in the total organic content (TOC) along the depth of the filter (data not shown), we inferred that the $\mathrm{C}$ mainly arose from the alkalinity of the water and existed in the form of calcium carbonate and manganese carbonate, which was confirmed in previous studies [27].

Table 3. The elemental composition of the virgin sand and the filter media.

\begin{tabular}{ccccccccc}
\hline Element. & $\mathbf{C}$ & $\mathbf{O}$ & $\mathbf{N a}$ & $\mathbf{M g}$ & $\mathbf{S i}$ & $\mathbf{C a}$ & $\mathbf{M n}$ & Fe \\
\hline Virgin sand (\%) & & 65.38 & & & 34.62 & & & \\
Filter media (\%) & 20.74 & 52.29 & 0.91 & 0.70 & 10.62 & 1.68 & 8.46 & 4.60 \\
\hline
\end{tabular}

\subsubsection{Element Distribution Analysis}

Multi-elemental EDS mapping images of the surface of the filter media are shown in Figure 10. Apparently, there was an abundance of $\mathrm{O}, \mathrm{Mn}, \mathrm{Mg}, \mathrm{Fe}, \mathrm{Ca}$ and $\mathrm{Si}$. And the elemental distribution was homogeneous across the entire area of the surface of the filter media. According to the literature, the characteristic elemental distribution on the surface of filter media in this study was much different that of biological filter media. Heterogeneous distribution of $\mathrm{Fe}, \mathrm{Mn}$ and $\mathrm{C}$ was observed on the surface of an "aged" biofilter media [28]. Alain et al. reported that the origin of the coating was a possible cause for chemical heterogeneity in surface coatings [29].

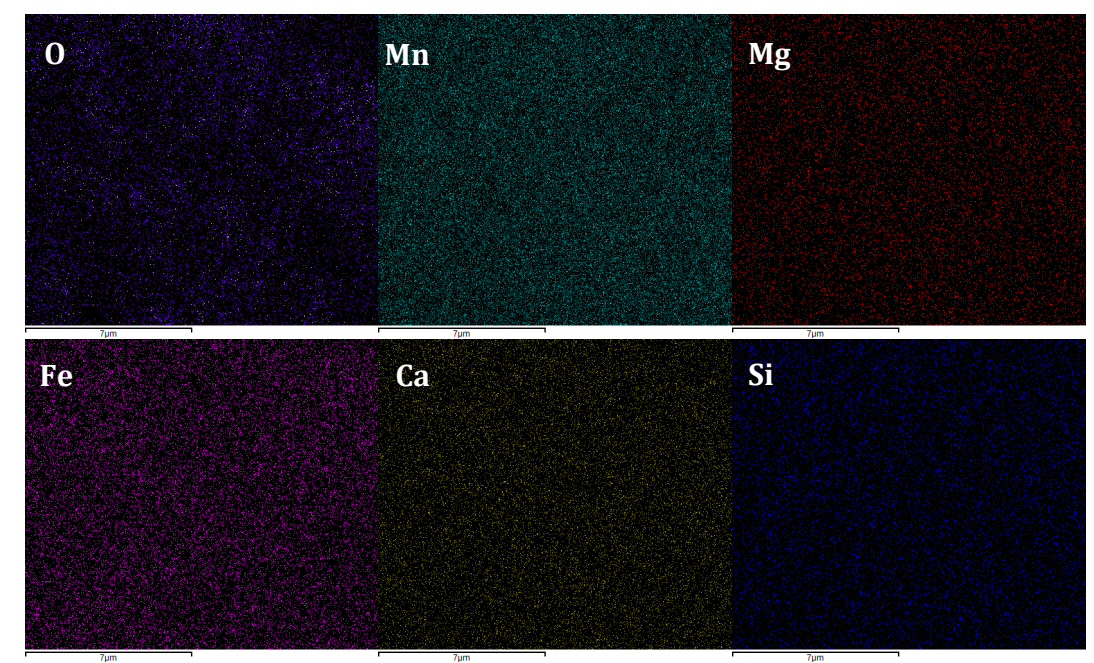

Figure 10. Multi-element energy dispersive spectrometry (EDS) mapping images of the filter media collected on the 20th day in filter R3.

\subsection{Comparison with Other Studies}

Based on our previous research [21], the start-up period of the filter column was further optimized in this study. The method for oxidation of $\mathrm{Mn}^{2+}$ and $\mathrm{Fe}^{2+}$ by $\mathrm{MnO}_{4}{ }^{-}$during the start-up period could guarantee that effluent $\mathrm{NH}_{4}{ }^{+}-\mathrm{N}$ would meet the drinking water standard by the fourth day, when the influent $\mathrm{NH}_{4}{ }^{+}-\mathrm{N}$ was $1.5 \mathrm{mg} / \mathrm{L}$. On the 18th day, the removal amount of $\mathrm{Mn}^{2+}$ reached $1 \mathrm{mg} / \mathrm{L}$, which would meet most of the drinking water treatment requirements. A comparison of the start-up period and the removal performance of $\mathrm{NH}_{4}{ }^{+}-\mathrm{N}$ and $\mathrm{Mn}^{2+}$ with other studies is shown in Table 4. Compared with other start-up methods, the method in our study has obvious advantages. 
Table 4. The comparison of the start-up period of $\mathrm{NH}_{4}{ }^{+}-\mathrm{N}$ and $\mathrm{Mn}^{2+}$ with other studies.

\begin{tabular}{|c|c|c|c|c|c|c|c|c|c|c|c|c|}
\hline \multirow{2}{*}{ Treatment System } & \multirow{2}{*}{ Media Types } & \multirow{2}{*}{ Temperature } & \multirow{2}{*}{ DO (mg/L) } & \multirow{2}{*}{$\mathrm{pH}$} & \multirow{2}{*}{ Backwashing } & \multicolumn{2}{|c|}{$\mathrm{c}\left(\mathrm{NH}_{4}{ }^{+}-\mathrm{N}\right)(\mathrm{mg} / \mathrm{L})$} & \multirow{2}{*}{ Period (day) } & \multicolumn{2}{|c|}{$\mathrm{c}(\mathrm{Mn})(\mathrm{mg} / \mathrm{L})$} & \multirow{2}{*}{ Period (Day) } & \multirow{2}{*}{ Reference } \\
\hline & & & & & & Influent & Effluent & & Influent & Effluent & & \\
\hline Pilot-scale filter & Quartz sand & $15-18$ & $5-7$ & $7.5-7.8$ & 2 day & 1.5 & $<0.1$ & 6 & 1.0 & $<0.1$ & 18 & This study \\
\hline Pilot-scale filter & Quartz sand & $6.6-22$ & $6.5-7.0$ & $7.9-8.1$ & & $1.39 \pm 0.10$ & 0.28 & 19 & $0.99 \pm 0.12$ & $<0.1$ & 26 & [22] \\
\hline Pilot-scale biofilter & Mn Sand & 8 & 8 & - & 2 day & 1.4 & $<0.1$ & 31 & 1.2 & $<0.05$ & 51 & [15] \\
\hline Pilot Mn removal filter & Quartz sand & $10.5-12.5$ & $8-9.5$ & $7.5-7.9$ & 2 weeks & - & & - & $0.1-0.15$ & 0 & 25 & [30] \\
\hline Bench-scale biofilter & Sand & - & reducing conditions & 6.5 & - & - & & - & $0.1-0.3$ & $<0.05$ & 42 & [12] \\
\hline Lab-scale biofilters & Quartz sand & $18-22$ & $7.8-8.5$ & $7.5-7.8$ & - & 1.2 & $<0.1$ & 13 & 0.8 & $<0.05$ & 30 & [19] \\
\hline Lab-scale biofilters & Sand & $>20$ & $7.5-8$ & 7.7 & weekly & & & - & 0.5 & 0 & 90 & [2] \\
\hline
\end{tabular}

DO: Dissolved oxygen. 


\section{Conclusions}

In the present study, an optimization method for the start-up of a $\mathrm{NH}_{4}{ }^{+}-\mathrm{N}$ and $\mathrm{Mn}^{2+}$ removal filter for drinking water treatment was proposed. The chemical oxidation method effectively shortened the start-up period of the filters. The operational factors of the influent $\mathrm{Mn}^{2+}$ concentration, $\mathrm{Fe}^{2+}$ concentration, filtration rate and dosing time were optimized. The optimum conditions were found to be $1.5 \mathrm{mg} / \mathrm{L} \mathrm{NH}_{4}{ }^{+}-\mathrm{N}, 2 \mathrm{mg} / \mathrm{L} \mathrm{Mn}^{2+}, 1.5 \mathrm{mg} / \mathrm{L} \mathrm{Fe}^{2+}$, a $4 \mathrm{~m} / \mathrm{h}$ filtration rate and the duration of dosing time was 14 days. During the start-up period, the specific surface area of the filter media increased along with prolonging the running time, which provided more active sites for $\mathrm{NH}_{4}{ }^{+}-\mathrm{N}$ catalytic oxidation. During the start-up period, frequent backwashing was not favorable to the formation of the $\mathrm{NH}_{4}{ }^{+}-\mathrm{N}$ and $\mathrm{Mn}^{2+}$ removal ability of the filters. The start-up periods of all filters in this study were much faster than those of biofilters. This study has shown that the use of an iron-manganese co-oxide filter could be an effective system for catalytic oxidation to remove $\mathrm{NH}_{4}{ }^{+}-\mathrm{N}$ and $\mathrm{Mn}^{2+}$ from drinking water.

Author Contributions: Y.C., T.H. and J.W. worked together. Specifically, T.H. proposed the idea. Y.C. designed the study and interpreted the results. Y.C., L.C. and J.W. performed the experiments.

Acknowledgments: This work was supported by the National Key Research and Development Program of China (No. 2016YFC0400706), the Natural Science Foundation of China (No. 51778521) and the Natural Science Basic Research Plan in Shaanxi Province of China (No. 2017JQ2014).

Conflicts of Interest: The authors declare no conflict of interest.

\section{References}

1. Hasan, H.A.; Abdullah, S.R.S.; Kamarudin, S.K.; Kofli, N.T.; Anuar, N. Simultaneous $\mathrm{NH}_{4}{ }^{+}-\mathrm{N}$ and $\mathrm{Mn}^{2+}$ removal from drinking water using a biological aerated filter system: Effects of different aeration rates. Sep. Purif. Technol. 2013, 118, 547-556. [CrossRef]

2. Hoyland, V.W.; Knocke, W.R.; Rd, F.J.; Pruden, A.; Singh, G. Effect of drinking water treatment process parameters on biological removal of manganese from surface water. Water Res. 2014, 66, 31-39. [CrossRef] [PubMed]

3. Hasan, H.A.; Abdullah, S.R.S.; Kamarudin, S.K.; Kofli, N.T. On-off control of aeration time in the simultaneous removal of ammonia and manganese using a biological aerated filter system. Process Saf. Environ. 2013, 91, 415-422. [CrossRef]

4. Cai, Y.; Li, D.; Liang, Y.; Zeng, H.; Zhang, J. Autotrophic nitrogen removal process in a potable water treatment biofilter that simultaneously removes $\mathrm{Mn}$ and $\mathrm{NH}_{4}{ }^{+}-\mathrm{N}$. Bioresour. Technol. 2014, 172, $226-231$. [CrossRef] [PubMed]

5. Cheng, Y.; Huang, T.; Shi, X.; Wen, G.; Sun, Y. Removal of ammonium ion from water by Na-rich birnessite: Performance and mechanisms. J. Environ. Sci. 2017, 57, 402-410. [CrossRef] [PubMed]

6. Hasan, H.A.; Abdullah, S.R.S.; Kamarudin, S.K.; Kofli, N.T. Effective curves of completing simultaneous ammonium and manganese removal in polluted water using a biological aerated filter. J. Ind. Eng. Chem. 2015, 30, 153-159. [CrossRef]

7. Broséus, R.; Cigana, J.; Barbeau, B.; Daines-Martinez, C.; Suty, H. Removal of total dissolved solids, nitrates and ammonium ions from drinking water using charge-barrier capacitive deionisation. Desalination 2009, 249, 217-223. [CrossRef]

8. Liao, Z.L.; Chen, H.; Zhu, B.R.; Li, H.Z. Combination of powdered activated carbon and powdered zeolite for enhancing ammonium removal in micro-polluted raw water. Chemosphere 2015, 134, 127-132. [CrossRef] [PubMed]

9. Charerntanyarak, L. Heavy metals removal by chemical coagulation and precipitation. Water Sci. Technol. 1999, 39, 135-138. [CrossRef]

10. Choo, K.-H.; Lee, H.; Choi, S.-J. Iron and manganese removal and membrane fouling during UF in conjunction with prechlorination for drinking water treatment. J. Membr. Sci. 2005, 267, 18-26. [CrossRef]

11. Pacini, V.A.; María, I.A.; Sanguinetti, G. Removal of iron and manganese using biological roughing up flow filtration technology. Water Res. 2005, 39, 4463-4475. [CrossRef] [PubMed] 
12. Burger, M.S.; Mercer, S.S.; Shupe, G.D.; Gagnon, G.A. Manganese removal during bench-scale biofiltration. Water Res. 2008, 42, 4733-4742. [CrossRef] [PubMed]

13. Tekerlekopoulou, A.G.; Pavlou, S.; Vayenas, D.V. Removal of ammonium, iron and manganese from potable water in biofiltration units: A review. J. Chem. Technol. Biotechnol. 2013, 88, 751-773. [CrossRef]

14. Lytle, D.A.; Sorg, T.J.; Muhlen, C.; Wang, L.; Rahrig, M.; French, K. Biological nitrification in a full-scale and pilot-scale iron removal drinking water treatment plant. Aqua 2007, 56, 125-136. [CrossRef]

15. Cheng, Q. Competitive mechanism of ammonia, iron and manganese for dissolved oxygen using pilot-scale biofilter at different dissolved oxygen concentrations. Water Sci. Technol. Water Supply 2016, 16, 766-774. [CrossRef]

16. Štembal, T.; Markić, M.; Ribičlć, N.; BrišKi, F.; Sipos, L. Removal of ammonia, iron and manganese from groundwaters of northern Croatia-Pilot plant studies. Process Biochem. 2005, 40, 327-335. [CrossRef]

17. Tekerlekopoulou, A.G.; Vayenas, D.V. Simultaneous biological removal of ammonia, iron and manganese from potable water using a trickling filter. Biochem. Eng. J. 2008, 39, 215-220. [CrossRef]

18. Han, M.; Zhao, Z.W.; Gao, W.; Cui, F.Y. Study on the factors affecting simultaneous removal of ammonia and manganese by pilot-scale biological aerated filter (BAF) for drinking water pre-treatment. Bioresour. Technol. 2013, 145, 17-24. [CrossRef] [PubMed]

19. Cai, Y.; Li, D.; Liang, Y.; Luo, Y.; Zeng, H.; Zhang, J. Effective start-up biofiltration method for Fe, Mn and ammonia removal and bacterial community analysis. Bioresour. Technol. 2015, 176, 149-155. [CrossRef] [PubMed]

20. Puyen, Z.M.; Villagrasa, E.; Maldonado, J.; Diestra, E.; Esteve, I.; Solé, A. Biosorption of lead and copper by heavy-metal tolerant Micrococcus luteus DE2008. Bioresour. Technol. 2012, 126, 233. [CrossRef] [PubMed]

21. Cheng, Y.; Huang, T.; Sun, Y.; Shi, X. Catalytic oxidation removal of ammonium from groundwater by manganese oxides filter: Performance and mechanisms. Chem. Eng. J. 2017, 322, 82-89. [CrossRef]

22. Guo, Y.; Huang, T.; Wen, G.; Cao, X. The simultaneous removal of ammonium and manganese from groundwater by iron-manganese co-oxide filter film: The role of chemical catalytic oxidation for ammonium removal. Chem. Eng. J. 2017, 308, 322-329. [CrossRef]

23. Cheng, Y.; Li, Y.; Huang, T.; Sun, Y.; Shi, X.; Shao, Y. A comparison study of the start-up of a $\mathrm{MnO}_{\mathrm{x}}$ filter for catalytic oxidative removal of ammonium from groundwater and surface water. J. Environ. Sci. 2018, 65, 327-334. [CrossRef] [PubMed]

24. Jiang, H.; Liu, G.-H.; Ma, Y.; Xu, X.; Chen, J.; Yang, Y.; Liu, X.H.; Wang, H.C. A pilot-scale study on start-up and stable operation of mainstream partial nitrification-anammox biofilter process based on online $\mathrm{pH}-\mathrm{DO}$ linkage control. Chem. Eng. J. 2018, 350, 1035-1042. [CrossRef]

25. Huang, T.; Cao, X.; Zhang, Q.; Su, Z.; Zheng, N. Catalytic oxidation of high-concentration ammonia in groundwater by a naturally formed co-oxide filter film. Desalin. Water Treat. 2014, 52, 1615-1623. [CrossRef]

26. Zhang, R.; Huang, T.; Wen, G.; Chen, Y.; Cao, X.; Zhang, B. Using iron-manganese co-oxide filter film to remove ammonium from surface water. Inter. J. Enviorn. Res. Public Health 2017, 14, 807. [CrossRef] [PubMed]

27. Cheng, Y.; Huang, T.; Cheng, L.; Sun, Y.; Zhu, L.; Li, Y. Structural characteristic and ammonium and manganese catalytic activity of two types of filter media in groundwater treatment. J. Environ. Sci. 2018. [CrossRef]

28. Sahabi, D.M.; Takeda, M.; Suzuki, I.; Koizumi, J. Removal of $\mathrm{Mn}^{2+}$ from water by "aged" biofilter media: The role of catalytic oxides layers. J. Biosci. Bioeng. 2009, 107, 151-157. [CrossRef] [PubMed]

29. Manceau, A.; Lanson, M.; Geoffroy, N. Natural speciation of Ni, Zn, Ba and as in ferromanganese coatings on quartz using X-ray fluorescence, absorption and diffraction. Geochim. Cosmochim. Acta 2007, 71, 95-128. [CrossRef]

30. Bruins, J.H.; Petrusevski, B.; Slokar, Y.M.; Huysman, K.; Joris, K.; Kruithof, J.C.; Kennefy, M.D. Biological and physico-chemical formation of Birnessite during the ripening of manganese removal filters. Water Res. 2015, 69, 154-161. [CrossRef] [PubMed]

(C) 2018 by the authors. Licensee MDPI, Basel, Switzerland. This article is an open access article distributed under the terms and conditions of the Creative Commons Attribution (CC BY) license (http:/ / creativecommons.org/licenses/by/4.0/). 